\title{
ANALYTICAL AND COMPARATIVE STUDY OF CHANGE IN FUNCTIONAL PURPOSE OF SOME ARCHAEOLOGICAL AND HISTORICAL ARCHITECTURES IN CAIRO DURING THE $19^{\text {th }}$ AND $20^{\text {th }}$ CENTURIES
}

\author{
Ghadeer Dardier Afify Khalifa \\ Islamic Department \\ Fayoum University \\ Al-Fayoum Governorate, Egypt, 63514 \\ gdk00@fayoum.edu.eg
}

\begin{abstract}
This research paper aims to discuss the nature of change in the functional purpose of some archaeological and historical buildings in Cairo during the 19th and 20th centuries along with a comparative study of some of the most important heritage constructions and evidences in the world, such as the British Museum in London, as well as the Historical Railway Station of Orsay in Paris. There are some practical attempts and technical procedures that have been carried out to achieve some functional purposes, differ from the original purposes of the archaeological and historical buildings in Cairo in particular. In a similar way, this has been applied to historical and heritage buildings around the world in general. The methodology of this study will be addressed through analytical and comparative study of the original idea or the original functional purpose of these archaeological and historical buildings. The outlines and features of change in the functional purpose of these archaeological and historical buildings are represented in some technical procedures like the technique of adaptive rehabilitation or rehabilitation in terms of adaptation, so there is a necessity for conformity and harmony between heritage buildings and modern functional purpose, and this should be done without any disagreement and repulsion with the original functional purpose. There is also a necessity to protect the original functional purpose, which should be adapted to the modern functional purpose in order to achieve compatibility between old and new integration processes.

Keywords: change, functional purpose, archaeological constructions, historical buildings, heritage architectures, 19th century, 20th century.
\end{abstract}

\section{Introduction}

There are some terms related to the content of this research paper, such as habilitation, rehabilitation, qualification, requalification, adaptation, readaptation, amendment, modification, modulation, improvement and modernization. The terminological or linguistic definition of these terms revolves around the functional purposes of architectural buildings in order to change the functional origin, adapt and keep up with contemporary developments; this in terms of compatibility, adaptation, integration and conjunction or synchronism between original and latter functional purposes [1-6]. It should be noted that the functional purposes, required from these linguistic terms, may differ in terms of the practical aspect, configuration and design methods, this is when there are some technical procedures that are performed in archaeological and historical buildings, these actions are a series of steps such as extension, elimination and reduction [1-9]. It is worth mentioning, that the original functional purpose appears to be suitable for the possibilities of heritage buildings in terms of architectural design and geometrical condition [7-15]. The term habilitation refers to technical processes that reinforce archaeological and historical buildings to attain, keep or improve their functioning in accordance with modern day requirements [16]. The term rehabilitation indicates to regain the quality of being efficient that may have been lost due to a change, it is also refers to recover the efficiency of heritage buildings once again after losing it [16]. With regard to qualification, requalification, adaptation, readaptation, amendment, modification, modulation, improvement, modernization [16], these terms are equal in meaning to habilitation and rehabilitation. In other words, these terms refer to practical actions and technical procedures that are implemented and applied to the functional purposes of archaeological and historical buildings in order to improve, modernize and refit their conditions in accordance with requirements of the modern era. The original functional purpose of some archaeological and historical buildings in Cairo during the 
$19^{\text {th }}$ and $20^{\text {th }}$ centuries is one of the effective agents of change, but it is worth mentioning, that the competent authorities should rehabilitate it with keeping its functional purposes, which related to social and doctrinal aspects, where the original functional value of the heritage building increases, when it seems to be a main part of the customs, traditions and culture of society. This attitude was also in London and Paris, where some heritage buildings were converted and changed, which are not functionally appropriate, therefore there is a necessity to modify these buildings to be adapted to other modern functional purposes. The objectives of this research paper will be clear through the examination, discussion, comparison and analysis, which can be addressed through a detailed investigation of the elements or structure of the content and context of this research paper in terms of the circumstances and procedures that form the setting for a statement, idea or theme of change in the functional purpose of some archaeological and historical buildings in Cairo during the $19^{\text {th }}$ and $20^{\text {th }}$ centuries, which can be fully understood and assessed through discussion and interpretation. It is worth mentioning, that there are many research papers, conducted by the researchers, which revolve around archaeological and historical buildings in Cairo during the $19^{\text {th }}$ and $20^{\text {th }}$ centuries, but they did not discuss and compare the theme of change in the functional purpose of some archaeological and historical buildings in Cairo during the $19^{\text {th }}$ and $20^{\text {th }}$ centuries in detail, which will be addressed through a comparative study. As a result, this study aims to research, discuss, identify and compare the features of change in the functional purpose in particular, this will be applied to some archaeological and historical buildings in Cairo during the $19^{\text {th }}$ and $20^{\text {th }}$ centuries, also this will be clear through a comparative study between these buildings and each other in Egypt and between them and the heritage buildings in London and Paris as aspects and features of the most famous historical and heritage evidence in the world. It should be noted, that the methodology and structure of this research paper will serve as a discussion of the content of the study.

\section{The Methodology and Structure of the Study}

The methodology and structure of the study will serve as a detailed investigation of the elements or structure of study, typically as a basis for discussion or interpretation, the methodology will be based on the examination, investigation, discussion and analysis, then the analytical context and conclusion of the content of the study. It is worth mentioning, that the methodology and structure of the study will be clear through the following points, which can be addressed through the outlines and features of change in functional purpose of archaeological and historical buildings in Cairo during the $19^{\text {th }}$ and $20^{\text {th }}$ centuries and in heritage buildings in general, which are represented in some technical procedures and linguistic terms, such as habilitation, rehabilitation, qualification, requalification, adaptation, readaptation, amendment, modification, modulation, improvement, modernization. It should be noted, that these terms revolve around the functional purposes of architectural buildings to change the functional origin, adapt and keep up with contemporary developments; this in terms of compatibility, adaptation, integration and conjunction or synchronism between original and latter functional purposes [1-6]. There is also a technical process of modification with various meanings, which involves establishing or founding something that was not before at the same way as it became after modification, modulation or amendment [16-18], as there is a technique of adaptive rehabilitation or rehabilitation in terms of adaptation, where there is a necessity for conformity and harmony between heritage buildings and modern functional purpose, this should be done without any disagreement and repulsion with the original functional purpose $[1,2,7-13,16]$. There is also integration into functional purposes [16], which is one of the most important technical processes, where there is a necessity to protecting the original functional purpose of heritage buildings in general, here the modern functional purpose should be adapted to the original functional purpose in order to attain functions, compatible with integration $[1,2,4,7-9$, $12,13]$. In case of deterioration of heritage buildings and no longer perform their original functional purpose and no longer in their functionally qualified case, here should sometimes be additions and necessary changes such as electronic networks and access and exit control networks, fire-resistant networks, sound systems, security alarms, ventilation and heating equipment, moreover there are some changes represented in some internal architectural elements such as fixed furniture, curtains, floors, lighting and fixed decorative elements, this can be done, but provided there is a necessity 
to protect architectural and historical characteristics, in addition to aesthetic or artistic function, as well as the functional aspect and purpose, which reflect the historical features of the past, also cultural and heritage values $[1-3,5,6,19]$. Changes and updates or so-called modernization can be added to heritage buildings through technical processes of renovation or re-evaluation and readjustment of some archaeological and historical buildings in Cairo during the $19^{\text {th }}$ and $20^{\text {th }}$ centuries in particular and heritage buildings in general. It is worth mentioning that the requirements of modern time imposed some changes that have emerged clearly in some archaeological and historical buildings in Cairo, dating back to the end of the $18^{\text {th }}$ century until the beginning of the $20^{\text {th }}$ century; these archaeological and historical buildings are being demolished in order to create modern buildings, although most of the façades of these buildings have valuable architectural elements, which are difficult to find an alternative under current conditions and poor implementation [2, 4-9]. From the above, it is clear that the archaeological, historical, architectural and geometrical values, as well as the functional purposes of heritage buildings must be preserved from any possibilities for change or modulations in functional purposes, in addition to the safeguard of aesthetic values, which include the artistic purposes and decorative manifestations. The safeguard of heritage sites in general and archaeological along with historical buildings, as well as architectural and functional purposes in particular lie in being a witness to the time of construction, architectural style, structural and geometrical design, as well as being a witness to decorative or artistic characteristics, technical values and functional purposes and in case of full or partial loss of these features, the milestones or features of substitution, modification and change will necessarily occur [20-22]. The procedures of change and modification or improvement may be internal or external, as may be done by adding architectural elements and also by removing or deleting, but it should be taken into account the need to refer to the decrees and decisions that have been passed for regarding these procedures, this is in the case of dealing with heritage sites in general, archaeological and historical buildings in particular and this is in order to determine permissible limits in cases of addition and omission or cancellation for a particular purpose and for overall change procedures [1-3]. It should be noted that there is a technique of compatibility or homogeneity in the general form of heritage buildings in terms of ratios and sizes, there are also homogeneity and symmetry techniques which applied to architectural elements, archaeological purposes, artistic values, decorative colors and the original characteristics in general; these techniques are associated with the concepts and features of technical treatments architecturally and visually [3-6].

In general, there was a multiplicity of suggestions for making changes in heritage buildings; it is worth mentioning that most of these suggestions were about the need for determinants and controls in change procedures, as these suggestions are often recommended that it should be limited in dealing with archaeological and historical buildings [2-5]. On the above, it is necessary to ask what is the role of International conventions in the changes that are added to heritage buildings in general and in archaeological and historical buildings in Cairo during the $19^{\text {th }}$ and $20^{\text {th }}$ centuries in particular? The International conventions have a role in controlling the issue of protecting the urban heritage in general, so there are laws and regulations, enacted in order to control the issue of changes in heritage buildings in terms of no changes are made in the planning of archaeological and historical buildings, as well as in their decorative values in addition to functional purposes [14, $15,23]$. Therefore, there are many charters and laws that call to keep monuments and heritage sites and protect them from distortion and tampering, as well as equip them with the current conditions of the age requirements. It is worth mentioning, that the planning and urbanization of cities was one of the most important societal concerns [10, 24], this should be done in accordance with the laws that provide for original architectural planning, composition and configuration. Thus, laws and legislation relating to the protection of architectural heritage have been enacted [10-13, 24, 25]. In 1964 the agreement of Venice had been issued, whose most important recommendations related to the change, modification and adjustment as technical processes of alteration and movement were applied in order to achieve the desired compatibility in appearance of archaeological and historical buildings or in heritage buildings in general. The Charter required that no essential changes be made in the planning of heritage buildings and stressed the need to maintain the architectural and historical style, artistic purpose and decorative values of the archaeological and heritage buildings 
$[14,15]$. In 1967, the final report of the meeting on the preservation and utilization of monuments and heritage sites, which contained archaeological, historical, artistic and functional purposes or values was issued through the forum for the safeguard of archaeological and historical buildings and related processes of change, configuration and restructuring the heritage sites and their relevance to historical values and archaeological purposes [26]. In 1972, the charter of the Budapest Symposium was issued and decided that heritage and historical architecture should be in collections of ancient archaeological buildings, as discussed the procedures of changes, renovations and the features of modernization, carried out in heritage sites or historical and heritage buildings. It has been stipulated, that change processes should take place without any internal or external effect on the planning and structural characteristics of heritage buildings, in addition to the necessity to safeguard and maintain their architectural style, artistic values and functional purposes [23]. In 1975, the decree of the International Symposium for preserving the historical cities was issued and stressed on the need for harmonization processes, in addition to the innovative activities, carried out in the historical cities or urban areas, and the need to improve and develop the public services of these areas in order to adapt the innovations of modern life and epochal requirements [27]. In October of 1975, the decree of the European Committee which concerns with the preservation of architectural heritage was issued and provided that change processes should be conducted in a very limited manner [28]. In 1976, the Nairobi decisions were issued in order to preserve historical sites and provided that there is a need to fit their functional role in accordance with the modern requirements [29]. There has been a multiplicity of charters and laws linked to the issue of safeguard of monuments and heritage sites and the need to protect them from distortion, modulations and theft. It should be noted, that there are some important recommendations issued, one of them was released in 1983 through the agreement of Appleton [30], besides the recommendations of ICOMOS Committee in the First Brazilian Conference in 1987, which was interested in the issue of safeguard of historical and heritage areas and the need to their rehabilitation [31], as well as the decree of ICOMOS Committee in New-Zealand in 1992, besides the decree of ICOMOS Committee in Burra in 1999 [32], these recommendations and charters were on the issue of safeguard and maintenance of heritage areas with archaeological value and historical character, besides the decree of ICOMOS Committee in New-Zealand which recommended the preservation of historical areas and heritage buildings [33].

With regard to Egypt, the Egyptian law of Antiquities No. 117, which issued in 1983, hadn't restricted the type of the function for archaeological buildings, but it should be the approval of the Permanent Committee of Supreme Council of Antiquities, which is required for any project relating to historical buildings, antiquities and archaeological sites [34, 35]. In Turkey, the change and rehabilitation processes in heritage areas have been classified into two types; the first one concerns with the concept of Negative Functions, which is related to the concepts of modification in heritage buildings and rehabilitation as museums, this in addition to the functional purposes of cultural lifestyles, relating to the ideas, customs, and social behavior of society. The second type is related to the concept of Active Functions, which deals with the technique of alteration in heritage buildings and the procedures of rehabilitation as shopping centers in order to fit and serve the functional purposes of economic concepts that provide revenue [36, 37]. In Madrid, the International Congress of Architects [38] issued a set of decrees and conditions for change and rehabilitation of heritage buildings; the item No. 3 dealt with the impossibility of change or modification in the original architectural style of heritage buildings; as well as the need to protect the architectural character, historical features, artistic characteristics and functional purposes which belong to archaeological and historical buildings $[2,3,38]$. The publication of the Italian restoration program or the so-called Carta del'Restauro Italiana 1931 [39] provided for the necessity of safeguard and visual treatment when making any changes or modifications in the heritage buildings, also recommended that procedures for full harmony between the original architectural elements of heritage buildings should be carried out, as well as focus on preserving the original historical, architectural and artistic purposes when dealing with archaeological and historical buildings [39]. It should be noted that the change procedures of heritage buildings include some techniques to be followed, such as compatibility, is a case in which two things are able to exist or occur together without problems or 
conflict, in addition to the replication technology that relates to the need for agreement or harmony according to compliance with standards, rules, or laws, this is when dealing with architectural and artistic elements of archaeological and historical buildings, so that it is difficult to distinguish between old and innovative elements [1-5, 7-9]. It is worth mentioning, that it is difficult to achieve, apply or implement the technique of change in the case of archaeological buildings, in addition to being completely contrary to the recommendations of the decrees concerned [3-6].

On the above, it is necessary to ask what is the role of studies that deal with and adopt change procedures in the archaeological and historical buildings? In this regard, there are some studies in connection with archaeological, historical and architectural buildings, where the processes of change and rehabilitation require some experimental and technical studies in order to apply the change procedures and the rehabilitation possibilities of heritage buildings. It is worth mentioning, that the most important studies are the Historical study [40], Architectural study $[41,42]$ and Structural study [42-44], these studies are interested in the extent of possibility to verify and for applying changes and rehabilitation of heritage buildings in general and of archaeological and historical buildings in particular. The importance of the historical studies is that they play an effective role in making decisions regarding these buildings; the historical studies illustrate the appropriate architectural elements for heritage buildings and clarify their relationship to historical events. Therefore, these studies control the procedures for adding and subtracting the architectural and geometrical elements of heritage buildings in general [40]. The importance of the architectural studies is that they evaluate the functional purposes and architectural values of heritage buildings, these studies also control the practical procedures in terms of changes and modifications of the appropriate architectural elements and their applicability to heritage buildings in general and to archaeological and historical buildings in particular [41, 42]. The structural studies are considered one of the important and effective steps to achieve compliance processes or procedures, as well as harmony or compatibility between the structure of heritage buildings and the loads that can be added, they also help to achieve the adjustment between the structure and expected loads. The structural studies also relate to procedures for applying changes and modifications and their reflection on heritage buildings in general. Furthermore, they help to calculate the resulting damage rates, and also help to support the structure of archaeological and historical buildings [42-44].

\section{Evidences of Change in the Functional Purpose of Some Archaeological and Historical Architectures in Cairo during the $19^{\text {th }}$ and $20^{\text {th }}$ Centuries}

The evidences of change in the functional purpose, as well as modification which clearly emerged in some archaeological and historical buildings in Cairo during the $19^{\text {th }}$ and $20^{\text {th }}$ centuries are present, and thus these evidences can be studied and addressed through the following architectural models that prove the phenomenon of change in the functional purpose, modification and rehabilitation of some archaeological and historical buildings in Cairo, this phenomenon can be rooted and manifested through the following evidences;

\section{1. The Islamic Village of Al-Qasr}

There is an evidence that proves the phenomenon of change in the functional purpose, modification and rehabilitation of historical buildings and of heritage sites, where the change processes, modification and rehabilitation procedures are carried out without any internal or external effect on the geometrical, structural designs, architectural characteristics and on the functional purposes of archaeological and historical buildings. This technique is represented in the Islamic village of Al-Qasr [45-47], which is located in the north of the city of Mut, the administrative capital of Dakhla Oasis, New Valley Governorate, Egypt. It is considered one of the first places that welcomed the Arabian and Islamic tribes almost in 50 A.H. and after the Islamic conquest of Egypt. Also, the village of Al-Qasr has a great flourish in the Ayyubid era. In this village, there are many historical buildings, represented in archaeological Palaces, Minarets and Old Mosques which date back to the Ayyubid, Mamluk and Ottoman eras. Moreover, there are some remains of a mosque dating back to the first century A.H., in addition to finding the ruins of the Roman governor's palace which name the village took $[48,49]$. It is worth mentioning, that this village still retains its architectural style, 
historical character and structural design and this has helped in the procedures of modification and rehabilitation to be an archaeological open-air museum or a heritage site (Fig. 1, a, b).

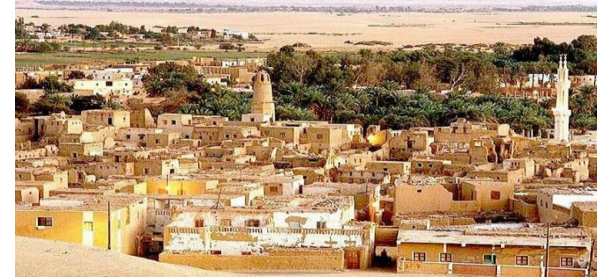

$a$

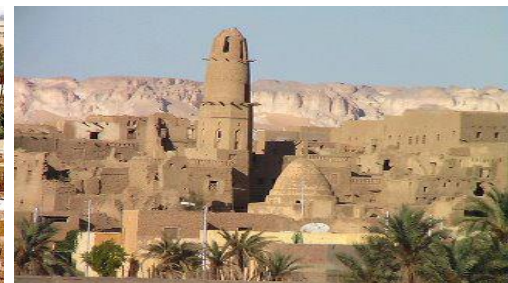

$b$

Fig. 1.The Historical Features of the City of al-Qasr in Dakhla Oasis, Egypt: $a$ - a general view of the City of al-Qasr in Dakhla Oasis; $b$ - more illustration of the City of al-Qasr in Dakhla Oasis (After: Ministry of Antiquities, Newsletter of the Egyptian Ministry of Antiquities, Second Issue, July 2016)

\section{2. Bayt El-Kredlea or the so-called Gayer-Anderson Museum}

The cultural activities are considered some of the most important effective factors to the processes of change in the functional purpose and the procedures of rehabilitation in order to use these archaeological buildings as museums and cultural symposium centers. It should be noted, that this occurred and evidenced through the procedures for the change and rehabilitation of some of these archaeological buildings, dating back to the Ottoman era, such as Bayt El-Kredlea [50-52], which built in 1041 A.H - 1631 A.D., this is according to writings, recorded on the ceiling of Sabil. This house is located near the eastern corner of the South-east wall of the Mosque of Ahmad Ibn Tulun in Cairo. In 1942, this Ottoman house is rehabilitated and turned into a museum, known as the Gayer-Anderson Museum [53-55], this is carried out to display some personal property of the England officer Gayer- Anderson (Fig. 2, $\boldsymbol{a}-\boldsymbol{d}$ ).

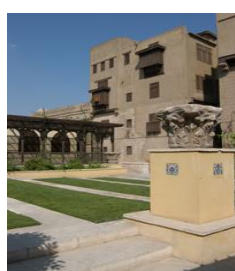

$a$

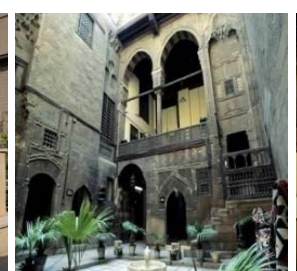

$b$

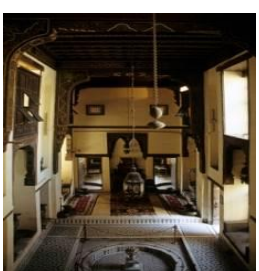

$c$

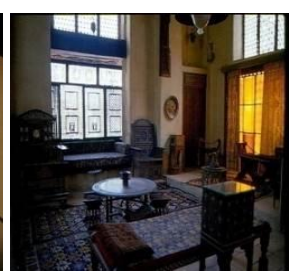

$d$

Fig. 2. Bayt El-Kredlea, the Ottoman house which is rehabilitated and turned into a museum, known as the Gayer-Anderson Museum, Cairo, Egypt $a$ - a general view of Bayt El-Kredlea; $b$ - an internal view of Bayt El-Kredlea; $c$ - a general features of the Gayer-Anderson Museum; $d$ - the artifacts are displayed inside the Gayer-Anderson Museum

(After: http://www.sca-egypt.org/eng/MUS_Gayer-Anderson.htm [Access date: 16/2/2018];

Warner, 2003)

This museum is important for being a perfect model of the style of houses in the Ottoman era. It is worth mentioning, that there were many evidences and features, represented the practical procedures, related to change and rehabilitation of some historical palaces in Egypt, which dates back to the era of Dynasty of Muhammad Ali Pasha [50-52, 56].

\section{3. The Zawiya of Sheikh Ali Abi-Shubbak Al-Rifa'i}

There is an archaeological model, used as a guide to the procedures of change in the functional purpose, modification and modernization or renovation, this is represented and emerged in the Mosque of Al-Rifa'i, which located in the square of Remila [57, 58]. It is worth mentioning, that there is change and substitution or replacement, where in the old site there was a pre-existing 
shrine, known as Zawiya of Sheikh Ali Abi-Shubbak Al-Rifa'i, this Zawiya or corner which is a part, region, or area, especially one regarded as sacred corner, dedicated to someone, in our case this Zawiya was dedicated to Sheikh Ali Abi-Shubbak Al-Rifa'i, which was a site for some people, who believed that the shrine is linked to mystical healing properties, the Mosque of Al-Rifa'i took the name of the prior Zawiya or the former Shrine of Sheikh Ali Abi-Shubbak Al-Rifa'i. It should be noted, that the Mosque of Al-Rifa'i was constructed by a command of Khushyar Hanim, the mother of Khedive Ismail, almost in 1286 A.H - 1829 A.D. [57, 58] (Fig. 3, a-d).

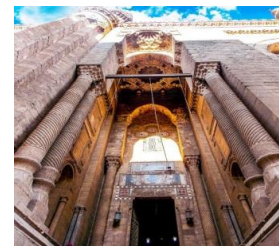

$a$

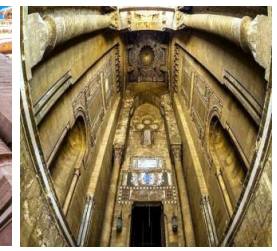

$b$

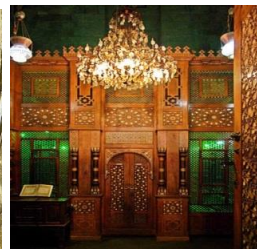

$c$

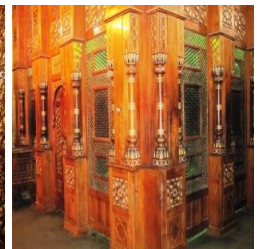

$d$

Fig. 3. The Mosque of Al-Rifa'i and the pre-existing shrine, known as the Zawiya of Sheikh Ali Abi-Shubbak Al-Rifa'i: $a$ - a general view of the main entrance of Al-Rifa'i Mosque;

$b$ - more illustration of the main entrance of Al-Rifa'i Mosque; $c$ - the Mausoleum or Zawiya of Sheikh Ali Abi-Shubbak Al-Rifa'i; $d$-more illustration of the Zawiya of Sheikh Ali Abi-Shubbak Al-Rifa'i (By: The Researcher)

\section{4. The Palace of El Gezirah or the so-called Cairo Marriott Hotel}

The techniques and processes of change in the functional purpose and procedures of compatibility or homogeneity were carried out in the general form of architectural buildings in terms of ratios, sizes, archaeological elements, decorative colors, artistic values, related to the technical methods architecturally and visually. This is what happened with one of the most important hotels in Cairo, known as Cairo Marriott Hotel, which is one of the examples of hotels that have a historical character in Cairo; it was built by Khedive Ismail in 1869 in order to be used as a palace [59-64]. In 1879, this palace had a main transition of its history, where the International Company of Marriott took over its management and renewed, qualified and configured it, as well as constructed two towers on its two sides to have 1250 luxurious rooms and suites; this is with retention of the main palace as a site for reception and meeting halls. The technique of compatibility or homogeneity was used through separating the palace from the two towers and this was through two paths; one of them contained a bazar and the other contained a casino. Moreover, some internal changes and modifications have been made, these changes and modifications were related to the rearrangement of inner spaces of the palace and after making the required changes and modifications, the hotel was opened in 1982 [59-64] (Fig. 4, a-c).

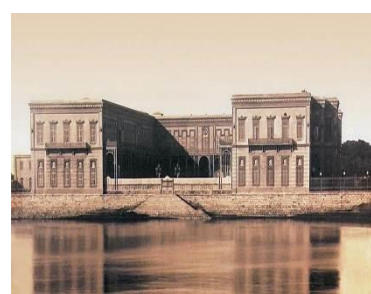

$a$

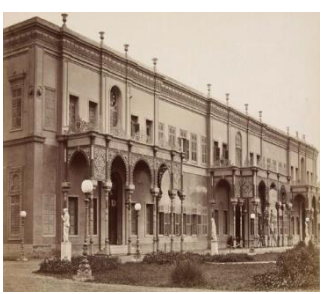

$b$

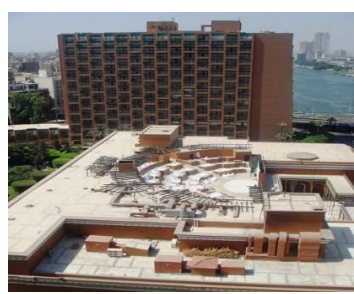

Fig. 4. The Historical Features of the Palace of El Gezirah, which is now known as the Cairo Marriott Hotel: $a$ - a general view of the old site of the Palace of El Gezirah; $b$ - more illustration of the historical features of El Gezirah Palace; $c$ - the new character of El Gezirah Palace, known as the Cairo Marriott Hotel (After: Pflugradt, 2013;

http://www.historichotels.com.eg/en/cairo-marriott/9-hotels/cairo-marriott.html [Access date: 15/2/2018]) 


\section{5. The Palace of Al-Za'faran}

The features of change in the functional purpose, modification and adaptation were emerged through the change in the regime system in Egypt from the Royal rule to the Republican rule. Therefore, there is an example of change in the functional purpose and rehabilitation and this was resulted from the phenomenon of reuses and rehabilitation of some palaces and royal rests which had a historical character, artistic value and architectural style in addition to the splendor of their internal elements. These royal palaces and rests possessed a change in the functional purpose through improvement procedures; this is carried out in order to fit the innovative functional role or purpose [2-5, 7-9]. It was noted, that this was represented and clearly emerged in the Palace of Al-Za'faran, which was built in the era of Khedive Ismail almost in 1870 [65-67], this palace consists of three clipped houses to be a palace. In 1876, Khedive Ismail made some changes, modifications and modernizations or renovations for the palace to be suitable for the stay of his brother Musta-fa Pasha Fadel and his family after their coming back from Astana [68]. It is worth mentioning, that this palace was constructed as the same way of Palace of Versailles in France $[69,70]$, which witnessed the education of Khedive Ismail. Furthermore, this palace was built on the ruins of an-other palace, known as El-Hasswa Palace, which was built by Muhammad Ali Pasha. It should be noted, that the palace of Al-Za'faran became the administrative headquarter of the University of Ain-Shams in Egypt; this palace had witnessed a lot of historical events in Egypt during this pe-riod, such as the British occupation of Egypt. It also witnessed the signing of 1936 treaty between Egypt and Britain, this palace now is under the authority of Ain-Shams University since 1952. Al-Za'faran palace still has its elegant architectural style and wealthy artistic decorative elements, which can be noticed in the Arches of windows, Balconies and Pillars of Facades and Jamat or the so-called Medallions that can be defined as a circular or an oval frame, decorated with the Royal Crown [71, 72] (Fig. 5, $\boldsymbol{a}, \boldsymbol{b}$ ).

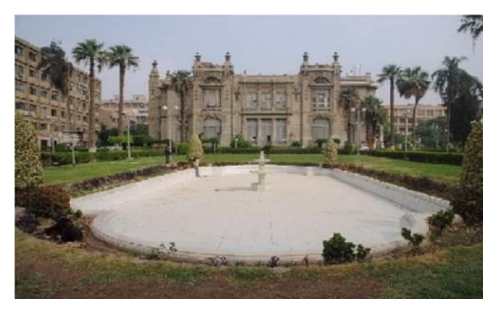

$a$

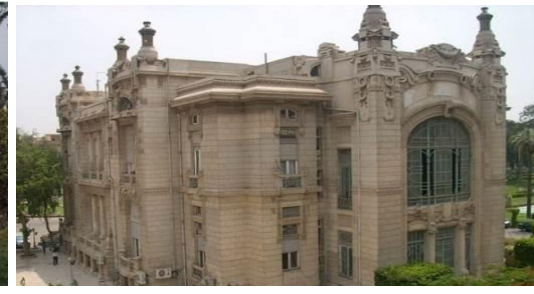

$b$

Fig. 5. The Historical Features of the Palace of Al-Za'faran, Egypt:

$a$-a general view of the Palace of Al-Za'faran; $b$ - more illustration of the historical features of Al-Za'faran Palace (After: http://www.shams.edu.eg/article.php?action=show\&id=6201

[Access date : 15/2/2018])

\section{6. The Palace of Abdeen}

There are effective factors of the processes of change in the functional purpose and procedures of rehabilitation, these factors include the historical value along with the architectural and artistic style of heritage buildings, especially if they have important and rich architectural or artistic elements, affirm the need for maintenance in order to still a historical and heritage witness throughout the eras. As well as, the structural system and geometrical design of these architectural buildings were effective agents for change actions and rehabilitation procedures, this is in order to be a witness to the functional purpose of these structural buildings throughout the ages $[1-5,7-9$, 38]. The most important example of this case is Abdeen Palace [68, 73-78], which had witnessed important historical events; it was built with the order of Khedive Ismail who ruled Egypt in 1863, and he built it with the help of the Architect Corielle Rosso. It is noteworthy, that Khedive Ismail was brought some Italian, French and Turkish artists to design its decorations. The name of this palace related to Abdeen Bey, who was one of the military commanders in the era of Muhammad Ali Pasha. The Abdeen Palace is considered a unique architectural building, rehabilitated and turned into a Palace with the Museum character to reflect the value and wealth in this era. It also reflects 
and witnesses the historical events in the Royal era till Revolution of 23 July 1952, as well as the importance of this palace lies in being a residence of the Regime since 1872 until 1952 [3, 74, 75, 78, 79] (Fig. 6, $\boldsymbol{a}, \boldsymbol{b})$.
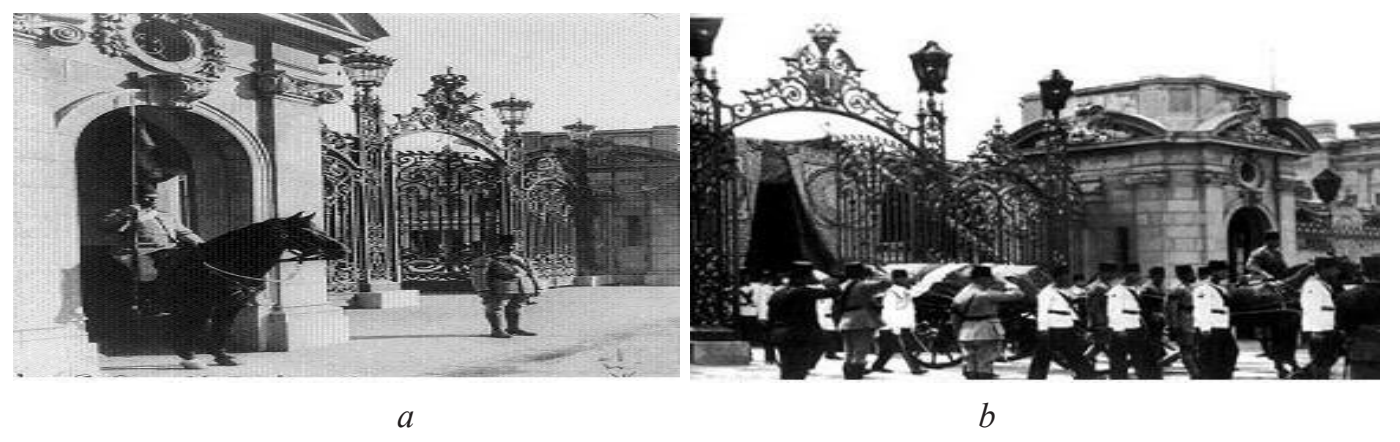

Fig. 6. The Historical Features of the Palace of Abdeen, Egypt $a-\mathbf{a}$ general view of the gates of Abdeen Palace; $b$ - in 1936, the King Fouad's casket leaves the Palace of Abdeen (After: Kramer, 1980)

\section{7. The Palace of Prince Mohammed Ali Tewfik}

The technique of internal changes of heritage buildings has been achieved through the procedures of rearrangement and rehabilitation of spaces and this is clearly shown in the Palace of Prince Mohammed Ali Tewfik, who was the son of Khedive Tewfik and the brother of Khedive Abbas Helmi II. This palace is located in Al-Rawda Island, Cairo, Egypt; it was built almost in 1901 , and currently included a shooting or hunting museum $[46,80]$. This palace was on a long path overlooked the palace garden; the spaces of this path was turned, changed and reformed or rehabilitated in order to be adapted to display the collectibles and collections which were collected from the palaces and rests of King Farouk and Prince Youssef Kamal, who were known for their interest in archery. The processes of change in the functional purpose, as well as procedures of configuration and modification of the museum, completed almost in 1963, this was after many years from the death of Prince Mohammed Ali Tewfik [80-83] (Fig. 7, $\boldsymbol{a}-\boldsymbol{c}$ ).

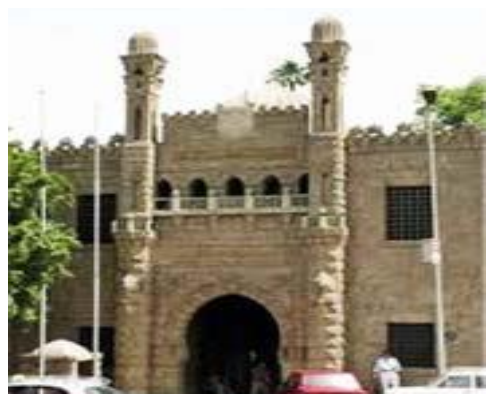

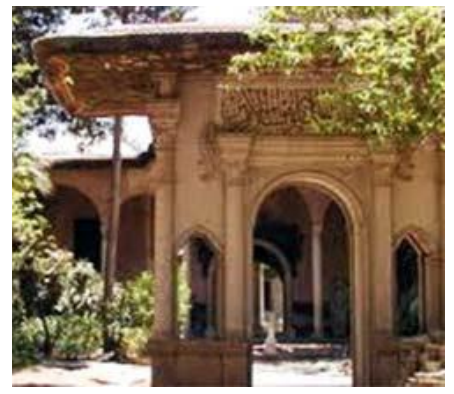

$b$

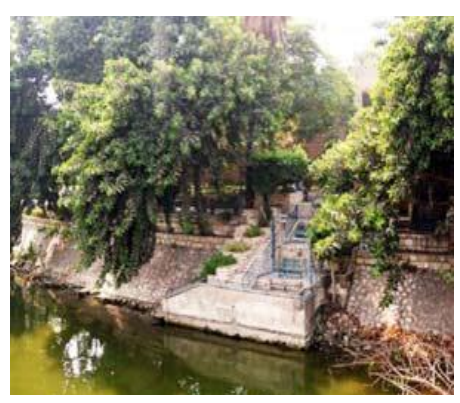

$c$

Fig. 7. The Historical Features of the Manial Palace, Egypt

$a$-a general view of the gate of the Manial Palace;

$b$ - an internal view of the Manial Palace; $c$ - a general view of the garden of the Manial Palace

(After: Abdel-Rahman, 2016)

The Muhammad Ali Museum in Manial El-Roda includes mainly artifacts of the royal family; the development or improvement of this museum has a specific beginning to an epochal scenario, innovative installations and up-to-date lighting. The changes, improvements and amendments, carried out to this museum, will allow major artifacts to be the focus of attention in a spectacular way [84] (Fig. 8, a, b). 


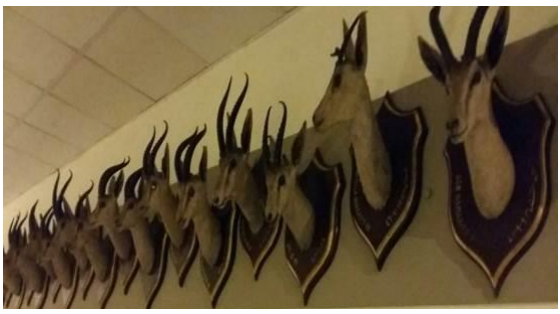

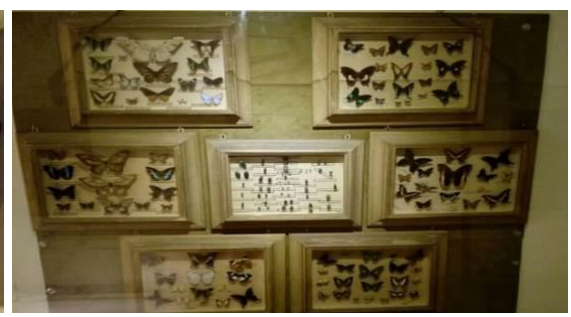

$b$

Fig. 8. The artifacts are displayed in the the Muhammad Ali Museum, which was previously known as the Palace of Manial el-Roda, Egypt: $a$ - some of the exhibits in the Muhammad Ali Museum; $b$ - some other exhibits are displayed in the Muhammad Ali Museum

(By: The Researcher)

\section{8. The Palace of Princess Samiha Kamel}

The procedures of internal changes and modifications were applied to the palace of Princess Samiha Kamel, who was the granddaughter of Khedive Ismail, she was born in 1889, and got a great care from her father Sultan Hussein Kamel, and she had a lot of cultural and artistic interests. Her palace is located in Zamalek area of Cairo and it was built in the beginning of the first quarter of the $20^{\text {th }}$ Century; this palace was one of the palaces that had distinguished architectural style with Mamluk, Ottoman, European, Andalusian, and Moroccan styles. Therefore, it was registered in the Islamic Antiquities in 1990, and in 2001 it was rehabilitated and turned into the Greater Cairo Public Library in Zamalek [85-91]. With regard to the architectural style along with the addition of suitable and homogeneous architectural elements, as well as the artistic and architectural details of this heritage building, in this regard, it is noted, that this has happened without any mutation or shift in the façades of this historical palace (Fig. 9).

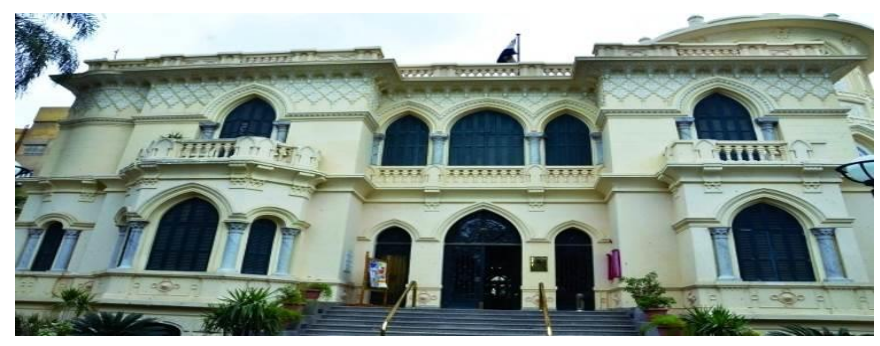

Fig. 9. The Palace of Princess Samiha Kamel, known as the Great Cairo Library (After:http://english.ahram.org.eg/News/28212.aspx [Access date: 15/2/2018]. http://egypt-d.com/?p=8437 [Access date: 15/2/2018])

\section{Evidences of Change in Functional Purpose of the Most Important Heritage Architectures in the World}

The change in functional purpose or the so-called modernism became the dominant global tendency in the $20^{\text {th }}$ century architecture and design. The phenomenon of modernism is the most important innovative style or philosophy of heritage architectures of the $20^{\text {th }}$ century, connected with an analytical approach to the functional purpose of archaeological and historical buildings. It is worth mentioning, that the architectural styles of the $20^{\text {th }}$ century were represented in the phenomenon of change along with improvement and safeguard or preservation and clearly emerged through the phenomenon of change in the functional purpose of heritage buildings. The evidences of change in the functional purpose, as well as modification, were emerged clearly in some heritage buildings in the world and it should be noted, that this study will be limited to heritage buildings in London and Paris as aspects and features of the most famous historical and heritage evidence in the world. Therefore, these evidences can be studied and addressed through the following architectural models; 


\section{1. The British Museum in London}

The British museum is one of the international applied models which have been changed, modified or rehabilitated. This museum is one of the most landmarks in London; it is also a mean of touristic attraction with its Hellenic style, which was established in 1753 A.D., and it was officially opened in 1759 A.D. [92-95]. After the increase of visitors, it became very crowded, so qualification and configuration processes were done according to the modern requirements, such as providing recreational spaces or venues to serve as shops and restaurants. They also redesigned or rehabilitated the inner yard spaces, which had a lot of books to turn it into a yard around the main reading hall and cover it with glass roofs, as well as designed oval exhibitions around the great circle hall and provide suitable stairs to the upper floors [96-99] (Fig. 10, a-d).

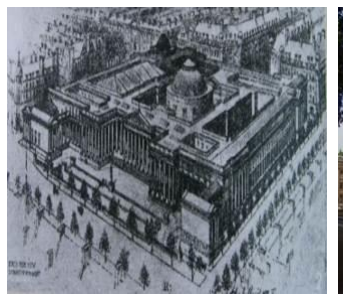

$a$

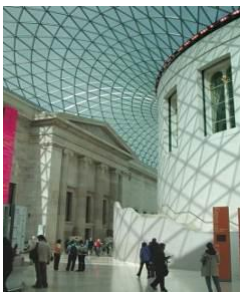

$c$

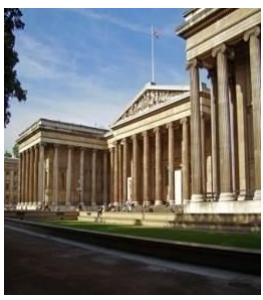

$b$

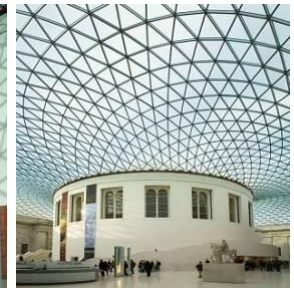

$d$

Fig. 10. The British Museum between the old character and new developments: $a$ - the proposed extension of the British Museum in 1906; $b$ - a general view of the entrance of the British Museum; $c$ - the great court of the British Museum after rehabilitation; $d$ - the reading room of the British Museum after rehabilitation (After: http://www.britishmuseum.org/

[Access date:16/1/2018])

It is clear in the previous model that the processes of changes and procedures of rehabilitation were used for treating the buildings and the ancient districts to be adapted to the requirements of innovative functional purpose. These processes, procedures and techniques can allow removing some other buildings around the heritage building to preserve the historical character and heritage buildings style, but the executors should be aware of architectural and geometrical designs of the building in order to keep its cultural significances and historical features. The heritage buildings should have architectural blocks according to geometrical designs related to the requirements of the era of their construction, so the procedures of change, rehabilitation and configuration should be depended on different policies such as improvement, redevelopment and maintenance, so the executors should choose ways, procedures and policies that are appropriate to maintain the historical character, architectural style, functional purposes and artistic values of heritage buildings [1-9].

\section{2. The Historical Railway Station of Orsay in Paris}

The character of distinctive architecture is one of the effective agents for change actions and rehabilitation procedures. The phenomenon of change in the functional purpose, modification and rehabilitation has been clearly emerged in heritage buildings in order to fit and adapt to other purposes, this is what happened in Europe with some buildings which weren't used functionally, so they required to be turned, reformed and rehabilitated by making changes in order to improve them, as well as to suit social and economic practices and to be adapted to another functional pur- 
pose. It is worth mentioning, that this has been applied to the historical railway station of Orsay in Paris, which turned into a museum almost in 1898 A.D., known as the Orsay Museum [6, 100]. It should be noted, that this case requires a lot of change actions and modifications in the axes and paths to be suitable for the innovative purpose with attention to the old style of the station and also the requirements for choosing places or the museum display locations [6, 100-103] (Fig. 11, a-e).

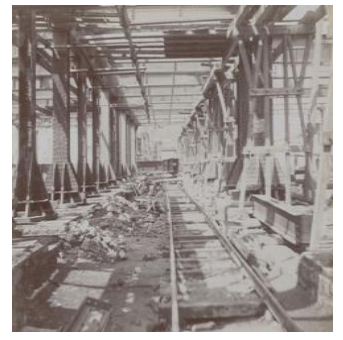

$a$

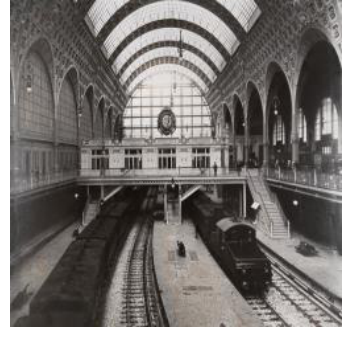

$b$

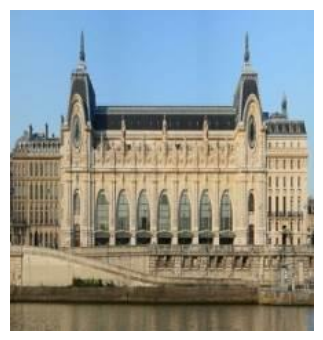

$c$

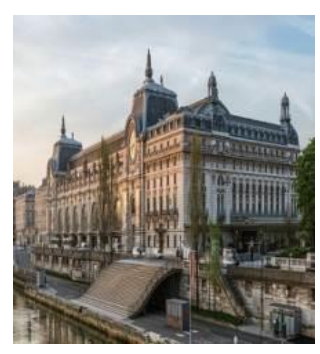

$d$

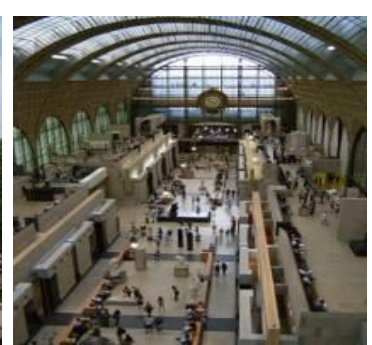

$e$

Fig. 11. Orsay railway station, located in the centre of Paris, on the left bank of the Seine River, and opposite the Tuileries Gardens, Paris: $a$ - the old site of Orsay railway station; $b$ - more illustration of the old site of Orsay railway station; $c$ - the Orsay museum which was installed in the former Orsay railway station, built for the Universal Exhibition of 1900; $d$ - more illustration of the Orsay museum which was installed in the former Orsay railway station, built for the

Universal Exhibition of 1900; $e$ - the interior Hall of the Museum of Orsay in Paris

(After: http://www.musee-orsay.fr/en/collections/history-of-the museum/home.html

[Access date:10/1/2018])

\section{Results of the Study}

1. From the study, it can be evidenced that there are a lot of concepts, related to the phenomenon of change in the functional purpose which clearly emerged in some archaeological and historical buildings in Cairo during the $19^{\text {th }}$ and $20^{\text {th }}$ centuries, such as modification, amendment, modulation, adjustment, alteration, replacement, substitution, habilitation, rehabilitation, qualification, requalification, adaptation, readaptation, improvement and modernization. The terminological or linguistic definition of these terms revolves around the functional purposes of architectural buildings in order to change the functional origin, adapt and keep up with contemporary developments; this in terms of compatibility, adaptation, integration and conjunction or synchronism between original and latter functional purposes.

2. The outlines and features of change in functional purpose of archaeological and historical buildings in Cairo during the $19^{\text {th }}$ and $20^{\text {th }}$ centuries and in heritage buildings in general are represented in some technical procedures, such as the technique of adaptive rehabilitation or rehabilitation in terms of adaptation, where there is a necessity for conformity and harmony between heritage buildings and modern functional purpose, this should be done without any disagreement and repulsion with the original functional purpose. There is also integration into functional purposes, which is one of the most important technical process, where there is a necessity to protecting the original functional purpose of heritage buildings in general, here the modern functional purpose should be adapted to the original functional purpose in order to attain functions, compatible with integration. 
3. In case of deterioration of heritage buildings and no longer perform their original functional purpose and no longer in their functionally qualified case, here should sometimes be additions and necessary changes, such as electronic networks and access and exit control networks, fire-resistant networks, sound systems, security alarms, ventilation and heating equipment, moreover there are some changes represented in some internal architectural elements such as fixed furniture, curtains, floors, lighting and fixed decorative elements, this can be done, but provided there is a necessity to protect architectural and historical characteristics, in addition to aesthetic or artistic function, as well as the functional aspect and purpose, which reflect the historical features of the past, also cultural and heritage values.

4. The changes and updates or so-called modernization can be added to heritage buildings through technical processes of renovation or re-evaluation and readjustment of some archaeological and historical buildings in Cairo during the $19^{\text {th }}$ and $20^{\text {th }}$ centuries in particular and heritage buildings in general. The requirements of modern time imposed some changes that have emerged clearly in some archaeological and historical buildings in Cairo, dating back to the end of the $18^{\text {th }}$ century until the beginning of the $20^{\text {th }}$ century. These archaeological and historical buildings are being demolished in order to create modern buildings, although most of the façades of these buildings have valuable architectural elements, which are difficult to find an alternative under current conditions and poor implementation.

5. The archaeological, historical, architectural and geometrical values, as well as the functional purposes of heritage buildings must be preserved from any possibilities for change or modulations in functional purposes, in addition to the safeguard of aesthetic values, which include the artistic purposes and decorative manifestations. The safeguard of heritage sites in general and archaeological along with historical buildings, as well as architectural and functional purposes in particular lie in being a witness to the time of construction, architectural style, structural and geometrical design, as well as being a witness to decorative or artistic characteristics, technical values and functional purposes and in case of full or partial loss of these features, the milestones or features of substitution, modification and change will necessarily occur.

6. There is a technique of compatibility or homogeneity in the general form of heritage buildings in terms of ratios and sizes, there are also homogeneity and symmetry techniques, carried out in architectural elements, archaeological purposes, artistic values, decorative colors and the original characteristics in general; these techniques are associated with the concepts and features of technical treatments architecturally and visually. Moreover, there was a multiplicity of suggestions for making changes in heritage buildings; the most of these suggestions were about the need for determinants and controls in change procedures, as these suggestions are often recommended that it should be limited in dealing with archaeological and historical buildings.

7. The agreements, recommendations and international decisions often control the processes of dealing with archaeological buildings or these which have historical and heritage characters, this is in order to achieve the main purposes and objectives which are represented in preserving the historical character, architectural style, geometrical design and artistic values of these buildings. The International conventions have a role in controlling the issue of protecting the urban heritage in general, so there are laws and regulations, enacted in order to control the issue of changes in heritage buildings in terms of no changes are made in the planning of archaeological and historical buildings, as well as in their decorative values in addition to functional purposes.

8. There are many charters and laws that call to keep monuments and heritage sites and to protect them from distortion and tampering, as well as equip them with the current conditions of the age requirements. These laws, legislation, agreement, conventions and charters include the agreement of Venice of 1964, the final report of the meeting on the preservation and utilization of monuments and heritage sites of 1967, the charter of the Budapest Symposium of 1972, the decree of the International Symposium of 1975, the decree of the European Committee of October 1975, the Nairobi decisions of 1976, the agreement of Appleton of 1983, the Egyptian law of Antiquities No. 117 of 1983, the recommendations of ICOMOS Committee in the First Brazilian Conference in 1987, the decree of ICOMOS Committee in New-Zealand in 1992, in addition to the decree of ICOMOS Committee in Burra in 1999. With regard to Turkey, the change and rehabilitation 
processes in heritage areas have been classified into two types; the concept of Negative Functions and the concept of Active Functions. Furthermore, there is the publication of the Italian restoration program or the so-called Carta del' Restauro Italiana of 1931.

9. There are some studies in connection with archaeological, historical and architectural buildings, where the processes of change and rehabilitation require some experimental and technical studies in order to apply the change procedures and the rehabilitation possibilities of heritage buildings. The most important studies are the Historical studies, Architectural studies and Structural studies, these studies are interested in the extent of possibility to verify and for applying changes and rehabilitation of heritage buildings in general and of archaeological and historical buildings in particular.

10. There are some evidences of change in the functional purpose, as well as modification which clearly emerged in some archaeological and historical buildings in Cairo during the $19^{\text {th }}$ and $20^{\text {th }}$ centuries. These architectural models that prove the phenomenon of change in the functional purpose, modification and rehabilitation can be rooted and manifested through the Islamic village of Al-Qasr. The cultural activities are considered some of the most important effective factors to the processes of change in the functional purpose and the procedures of rehabilitation in order to use these archaeological buildings as museums and cultural symposium centers, this is emerged through the procedures for the change and rehabilitation of some of these archaeological buildings dating back to the Ottoman era, such as Bayt El-Kredlea or the so-called Gayer-Anderson Museum.

11. There is an archaeological model, used as a guide to the procedures of change in the functional purpose, modification and modernization or renovation, this is represented and evidenced in Zawiya of Sheikh Ali Abi-Shubbak Al-Rifa'i, known as the Mosque of Al-Rifa'i. The techniques and processes of change in the functional purpose and procedures of compatibility or homogeneity were carried out in the general form of architectural buildings in terms of ratios, sizes, archaeological elements, decorative colors, artistic values, related to the technical methods architecturally and visually, and this is what happened with one of the most important hotels in Cairo, known as Cairo Marriott Hotel, which is one of the examples of hotels that have a historical character in Cairo. The features of change in the functional purpose, modification and adaptation were emerged through the Palace of Al-Za'faran.

12. There are effective factors of the processes of change in the functional purpose and procedures of rehabilitation, these factors include the historical value along with the architectural and artistic style of heritage buildings, especially if they have important and rich architectural or artistic elements, affirm the need for maintenance in order to still a historical and heritage witness throughout the eras. As well as, the structural system and geometrical design of these architectural buildings, this is evidenced in the Palace of Abdeen. The technique of internal changes of heritage buildings has been achieved through the procedures of rearrangement and rehabilitation of spaces and this is clearly shown in the Palace of Prince Mohammed Ali Tewfik, known as the Muhammad Ali Museum in Manial El-Roda, as well as the Palace of Princess Samiha Kamel, known as the Greater Cairo Public Library in Zamalek.

13. The change in functional purpose or the so-called modernism became the dominant global tendency in the $20^{\text {th }}$ century architecture and design, the phenomenon of modernism is the most important innovative style or philosophy of heritage architecture of the $20^{\text {th }}$ century, connected with an analytical approach to the functional purpose of archaeological and historical buildings. The evidences of change in the functional purpose, as well as modification were emerged clearly in some heritage buildings in the world such as London and Paris as aspects and features of the most famous historical and heritage evidence in the world.

14. The British museum in London is one of the international applied models which have been changed, modified or rehabilitated. The qualification and configuration processes were done according to the modern requirements. The processes of changes and procedures of rehabilitation were used for treating the buildings and the ancient districts to be adapted to the requirements of innovative functional purpose. These processes, procedures and techniques can allow removing some other buildings around the heritage building to preserve the historical character and heritage buildings style. 
15. The character of distinctive architecture is one of the effective agents for change a ctions and rehabilitation procedures. The phenomenon of change in the functional purpose, modification and rehabilitation has been clearly emerged in heritage buildings in order to fit and adapt to other purposes, this is what happened in Europe with some buildings, which weren't used functionally, so they required to be turned, reformed and rehabilitated by making changes in order to improve them, as well as to suit social and economic practices and to be adapted to another functional purpose. This is emerged in the historical railway station of Orsay in Paris, known as the Orsay Museum.

\section{Conclusion and Analysis of the Study}

This study focuses on the nature of change in the functional purpose of some archaeological and historical buildings in Cairo during the $19^{\text {th }}$ and $20^{\text {th }}$ centuries through a comparative study. Therefore, there are some practical attempts and technical procedures that have been carried out to achieve some functional purposes that differ from the original purposes of the archaeological and historical buildings in Cairo in particular, similarly this has been applied to historical and heritage buildings around the world in general. The methodology of this study has been addressed through a comparative study of the original idea or original functional purpose of these archaeological and historical buildings in Cairo during the $19^{\text {th }}$ and $20^{\text {th }}$ centuries in particular and the most famous historical and heritage evidences in the world, especially in London and Paris. The outlines and features of change in functional purpose of archaeological and historical buildings in Cairo during the $19^{\text {th }}$ and $20^{\text {th }}$ centuries and in heritage buildings in general are represented in some technical procedures such as the technique of adaptive rehabilitation or rehabilitation in terms of adaptation, where there is a necessity for conformity and harmony between heritage buildings and modern functional purpose, this should be done without any disagreement and repulsion with the original functional purpose. There is also integration into functional purposes which is one of the most important technical process, where there is a necessity to protecting the original functional purpose of heritage buildings in general, here the modern functional purpose should be adapted to the original functional purpose in order to attain functions, compatible with integration. In case of deterioration of heritage buildings and no longer perform their original functional purpose and no longer in their functionally qualified case, here should sometimes be additions and necessary changes such as electronic networks and access and exit control networks, fire-resistant networks, sound systems, security alarms, ventilation and heating equipment, moreover there are some changes represented in some internal architectural elements such as fixed furniture, curtains, floors, lighting and fixed decorative elements, this can be done, but provided there is a necessity to protect architectural and historical characteristics, in addition to aesthetic or artistic function, as well as the functional aspect and purpose, which reflect the historical features of the past, also cultural and heritage values. Changes and updates or so-called modernization can be added to heritage buildings through technical processes of renovation or re-evaluation and readjustment of some archaeological and historical buildings in Cairo during the $19^{\text {th }}$ and $20^{\text {th }}$ centuries in particular and heritage buildings in general. It is worth mentioning, that the requirements of modern time imposed some changes that have emerged clearly in some archaeological and historical buildings in Cairo, dating back to the end of the $18^{\text {th }}$ century until the beginning of the $20^{\text {th }}$ century; these archaeological and historical buildings are being demolished in order to create modern buildings, although most of the façades of these buildings have valuable architectural elements, which are difficult to find an alternative under current conditions and poor implementation. The archaeological, historical, architectural and geometrical values, as well as the functional purposes of heritage buildings must be preserved from any possibilities for change or modulations in functional purposes, in addition to the safeguard of aesthetic values, which include the artistic purposes and decorative manifestations. The safeguard of heritage sites in general and archaeological along with historical buildings, as well as architectural and functional purposes in particular lie in being a witness to the time of construction, architectural style, structural and geometrical design, as well as being a witness to decorative or artistic characteristics, technical values and functional purposes and in case of full or partial loss of these features, the milestones or features of substitution, modification and change 
will necessarily occur. There is a technique of compatibility or homogeneity in the general form of heritage buildings in terms of ratios and sizes, there are also homogeneity and symmetry techniques which applied to architectural elements, archaeological purposes, artistic values, decorative colors and the original characteristics in general; these techniques are associated with the concepts and features of technical treatments architecturally and visually. Moreover, there was a multiplicity of suggestions for making changes in heritage buildings; the most of these suggestions were about the need for determinants and controls in change procedures, as these suggestions are often recommended that it should be limited in dealing with archaeological and historical buildings. The International conventions have a role in controlling the issue of protecting the urban heritage in general, so there are laws and regulations, enacted in order to control the issue of changes in heritage buildings in terms of no changes are made in the planning of archaeological and historical buildings, as well as in their decorative values in addition to functional purposes. There are many charters and laws that call to keep monuments and heritage sites and protect them from distortion and tampering, as well as equip them with the current conditions of the age requirements. These laws, legislation, agreement, conventions and charters include the agreement of Venice of 1964, the final report of the meeting on the preservation and utilization of monuments and heritage sites of 1967, the charter of the Budapest Symposium of 1972, the decree of the International Symposium of 1975, the decree of the European Committee of October 1975, the Nairobi decisions of 1976, the agreement of Appleton of 1983, the Egyptian law of Antiquities No. 117 of 1983, the recommendations of ICOMOS Committee in the First Brazilian Conference in 1987, the decree of ICOMOS Committee in New-Zealand in 1992, in addition to the decree of ICOMOS Committee in Burra in 1999. With regard to Turkey, the change and rehabilitation processes in heritage areas have been classified into two types; the concept of Negative Functions and the concept of Active Functions. Furthermore, there is the publication of the Italian restoration program or the so-called Carta del' Restauro Italiana of 1931. There are some studies in connection with archaeological, historical and architectural buildings, where the processes of change and rehabilitation require some experimental and technical studies in order to apply the change procedures and the rehabilitation possibilities of heritage buildings. The most important studies are the Historical studies, Architectural studies and Structural studies, these studies are interested in the extent of possibility to verify and for applying changes and rehabilitation of heritage buildings in general and of archaeological and historical buildings in particular. There are some evidences of change in the functional purpose, as well as modification which clearly emerged in some archaeological and historical buildings in Cairo during the $19^{\text {th }}$ and $20^{\text {th }}$ centuries. These architectural models that prove the phenomenon of change in the functional purpose, modification and rehabilitation can be rooted and manifested through the Islamic village of Al-Qasr. The cultural activities are considered some of the most important effective factors to the processes of change in the functional purpose and the procedures of rehabilitation in order to use these archaeological buildings as museums and cultural symposium centers, this is emerged through the procedures for the change and rehabilitation of some of these archaeological buildings dating back to the Ottoman era, such as Bayt El-Kredlea or the so-called Gayer-Anderson Museum. There is an archaeological model used as a guide to the procedures of change in the functional purpose, modification and modernization or renovation, this is represented and evidenced in Zawiya of Sheikh Ali Abi-Shubbak Al-Rifa'i, known as the Mosque of Al-Rifa'i. The techniques and processes of change in the functional purpose and procedures of compatibility or homogeneity were carried out in the general form of architectural buildings in terms of ratios, sizes, archaeological elements, decorative colors, artistic values, related to the technical methods architecturally and visually, and this is what happened with one of the most important hotels in Cairo, known as Cairo Marriott Hotel, which is one of the examples of hotels that have a historical character in Cairo. The features of change in the functional purpose, modification and adaptation were emerged through the Palace of Al-Za'faran. There are effective factors of the processes of change in the functional purpose and procedures of rehabilitation, these factors include the historical value along with the architectural and artistic style of heritage buildings, especially if they have important and rich architectural or artistic elements, affirm the need for maintenance in order to still a historical and heritage witness throughout the eras. As well as, the structural system and geometrical design of 
these architectural buildings, this is evidenced in the Palace of Abdeen. The technique of internal changes of heritage buildings has been achieved through the procedures of rearrangement and rehabilitation of spaces and this is clearly shown in the Palace of Prince Mohammed Ali Tewfik, known as the Muhammad Ali Museum in Manial El-Roda, as well as the Palace of Princess Samiha Kamel, known as the Greater Cairo Public Library in Zamalek. The change in functional purpose or the so-called modernism became the dominant global tendency in the $20^{\text {th }}$ century architecture and design, the phenomenon of modernism is the most important innovative style or philosophy of heritage architecture of the $20^{\text {th }}$ century, connected with an analytical approach to the functional purpose of archaeological and historical buildings. The evidences of change in the functional purpose, as well as modification,were emerged clearly in some heritage buildings in the world such as London and Paris as aspects and features of the most famous historical and heritage evidence in the world. The British museum in London is one of the international applied models which have been changed, modified or rehabilitated. The qualification and configuration processes were done according to the modern requirements. The processes of changes and procedures of rehabilitation were used for treating the buildings and the ancient districts to be adapted to the requirements of innovative functional purpose. These processes, procedures and techniques can allow removing some other buildings around the heritage building to preserve the historical character and heritage buildings style. The character of distinctive architecture is one of the effective agents for change actions and rehabilitation procedures. The phenomenon of change in the functional purpose, modification and rehabilitation has been clearly emerged in heritage buildings in order to fit and adapt to other purposes, this is what happened in Europe with some buildings which weren't used functionally, so they required to be turned, reformed and rehabilitated by making changes in order to improve them, as well as to suit social and economic practices and to be adapted to another functional purpose, where this is emerged in the historical railway station of Orsay in Paris, known as the Orsay Museum.

\section{References}

[1] Osman, D. (2009). A methodology for developing urban pathways of Historical districts in Egypt. Egypt: Helwan University.

[2] Serageldin, I. (2002). Very Special Places: The Architecture and Economics of. Intervening in Historic Cities. Washington: World Bank Press, 65. University.

[3] Abdeen, N. (2009). Reusing Historical buildings as a reference to Conservation. Egypt: Cairo

[4] Henehan, D., Woodson, D., Culbert, S., (2004). Building Change-of-Use. Renovation, Adapting, and Altering Commercial, Institutional, and Industrial Properties. New York: McGraw-Hill Press.

[5] Yung, E. H. K., Chan, E. H. W. (2012). Implementation challenges to the adaptive reuse of heritage buildings: Towards the goals of sustainable, low carbon cities. Habitat International, 36 (3), 352-361. doi: http://doi.org/10.1016/j.habitatint.2011.11.001

[6] Feilden, B. M. (1982). Conservation of Historic buildings. London: Butterworth and Co.LTD Press, 272.

[7] Mohammed, A. M. (2006). Alt'amul Ma'a 'anaser Al'emarah Alddakhiliah fi Masharie E`adet Tawzif Almabani dhat Alqimah. Egypt: Cairo University.

[8] Mahmmoud, G. A. (2013). Taqyim Albadaeil Ertibatan Belmuetayat fi e'adat Estekhdam Almabany al'athariah, derasah e'ilmiah taqyimmiah fi altarmim walsianah tatbiqaan 'ale ahd almabany al'athariah bimadinat Alqaherah. Egypt: Cairo University.

[9] Ahmed, Z. A. (2008). Alma yir Alfaniyah le'adet Tawzif Almabany Kamatahif Tatabiqan biestikhdam Alhasib Alaly. Egypt: Cairo University.

[10] Abdul-Sattar, M. (1988). Al Madinah Al'Islamiah. Kuwait: Al-Resalah Press.

[11] Morris, J. (1972). History of Urban Form Prehistory to the Renaissance. London, 268.

[12] Claude, Ch. (1990). Les Villes du Monde Arabes. Paris: Masson Press, 556.

[13] Van Assche, K., Beunen, R., Duineveld, M., de Jong, H. (2012). Co-evolutions of planning and design: Risks and benefits of design perspectives in planning systems. Planning Theory, 12 (2), 177-198. doi: http://doi.org/10.1177/1473095212456771 
[14] Jokilehto, J. (1998). The context of the Venice Charter (1964). Conservation and Management of Archaeological Sites, 2 (4), 229-233. doi: http://doi.org/10.1179/135050398793138762

[15] The Venice Charter (1964). International Charter for the Conservation and Restoration of Monuments and Sites. Available at: https://www.icomos.org/charters/venice_e.pdf

[16] Harcourt, H. M. (Ed.) (2018). The American Heritage Dictionary of the English Language. USA Publishing Company. Available at: https://ahdictionary.com/word/search.html?q=define Last accessed: 10.01.2018

[17] Al-Jurjani, M. A. (1995). Ta’rīfāt. Cairo: Dar El Kotob for Printing \& Publishing.

[18] Academy of the Arabic Language (2010). Al Mu'jam al-Waseet, Bab al-Ta'a and Bab al-Ghayn. Cairo: Dar El Daawa for Printing \& Publishing.

[19] Langston, C., Wong, F. K. W., Hui, E. C. M., Shen, L.-Y. (2008). Strategic assessment of building adaptive reuse opportunities in Hong Kong. Building and Environment, 43 (10), 1709-1718. doi: http://doi.org/ 10.1016/j.buildenv.2007.10.017

[20] Keers, G., van der Reijden, H., van Rossum, H. (2011). Planning Archaeology: A Synthesis of the Thematic Sub-reports. Amsterdam: RIGO Research en Advies BV Press, 1-22.

[21] Building Archaeological Research Brochure. Netherland: Cultural Heritage Agency \& Association of Netherlands Municipalities, 1-4.

[22] Planning Policy Statements No.6: Planning, Archaeology and the Built Heritage (1999). Department of the Environment of Northern Ireland, 1-73.

[23] Resolutions of the Symposium on the introduction of contemporary architecture into ancient groups of buildings (1972). The 3rd ICOMOS General Assembly. Budapest. Available at: https://www.icomos.org/en/charters-and-texts/180-articles-en-francais/chartes-et-normes/383-resolutions-of-the-symposium-on-the-introduction-of-contemporary-architecture-into-ancient-groups-of-buildings-at-the-3rd-icomos-general-assembly

[24] Abdul-Whab, H. (1957). Takhtit Alqahereh Watanzimiha mundh Nasha'atiha. Cairo: Darannshr Press.

[25] Frank, K. (1984). Die Stadt im Altertum. München: Verlag C.H. Beck Press, 306.

[26] ICOMOS (1967). Final Report of the Meeting on the Preservation and Utilization of Monuments and Sites of Artistic and Historical Value. The Norms of Quito. Quito. Available at: https://www.icomos. org/en/what-we-do/involvement-in-international-conventions/standards/179-articles-en-francais/ressources/ charters-and-standards/168-the-norms-of-quito

[27] ICOMOS (1975). Resolutions of the International Symposium on the Conservation of Smaller Historic Towns. ICOMOS General Assembly. Available at https://www.icomos.org/en/resources/chartersand-texts/180-articles-en-francais/chartes-et-normes/384-resolutions-of-the-international-symposium-onthe-conservation-of-smaller-historic-towns-at-the-4th-icomos-general-assembly

[28] ICOMOS (1975). European Charter of the Architectural Heritage. Council of Europe. Available at: https://www.icomos.org/en/charters-and-texts/179-articles-en-francais/ressources/charters-and-standards/170-european-charter-of-the-architectural-heritage

[29] UNESCO (1976). Recommendation Concerning the Safeguarding and Contemporary Role of Historic Areas. Available at: http://portal.unesco.org/en/ev.php-URL_ID=13133\&URL_DO=DO_TOPIC\&URL_SECTION=201.html

[30] ICOMOS (1983). Appleton Charter for the Protection and Enhancement of the Built Environment. ICOMOS Canada. Available at: http:/orcp.hustoj.com/2016/01/04/appleton-charter-1983/

[31] ICOMOS (1987). First Brazilian Seminar about the Preservation and Revitalization of Historic Centers. Itaipava: ICOMOS Brazilian Committee. Available at: https:/www.icomos.org/en/charters-andother-doctrinal-texts/179-articles-en-francais/ressources/charters-and-standards/194-first-brazilian-seminar-about-the-preservation-and-revitalization-of-historic-centers-itaipava

[32] ICOMOS (1999). The Burra Charter, The Australia ICOMOS charter for the conservation of places of Cultural Significance. Available at: http://www.getty.edu/conservation/publications_resources/research_resources/charters/charter69aaa.html

[33] ICOMOS (2010). New Zealand Charter for the Conservation of Places of Cultural Heritage Value. Available at: http://www.gdc.govt.nz/assets/District-plan-text/Appendices/Appendix-06-Sep-12.pdf

[34] Al-Waqa'i', A.-M. (1983). Qanun Hemayat Alathar. Official Journal of Egypt, 117 (32). 
[35] Al-Waqa'i', A.-M. (2010). Qanun Hemayat Alathar. Official Journal of Egypt, 712 (153 (B)).

[36] Büyükdigan, I. (2003). A critical look at the new functions of Ottoman baths. Building and Environment, 38 (4), 617-633. doi: http://doi.org/10.1016/s0360-1323(02)00184-1

[37] Inanici, M. (2014). Lighting Analysis of Hagia Sophia. Annuals of Hagia Sophia Museum, $17,128-202$.

[38] Sixth International Congress of Architects (1904). Recommendations of the Madrid Conference, 1-7. Available at: http://www.getty.edu/conservation/publications_resources/research_resources/charters/charter01.html

[39] Consiglio Superiore per le Antichitá e belle Arti (1931). Carta del restauro Italiana. Available at: www.unipa.it/restauro Last accessed: 15.12.2017

[40] Martin, R., der Dussen, W. J. V., Rubinoff, L. (1993). Objectivity and Meaning in Historical Studies: Toward a Post-Analytic View. History and Theory, 32 (1), 25-50. doi: http://doi.org/10.2307/ 2505328

[41] Herbert, D. (1993). Architectural Study Drawings. New York: John Wiley \& Sons Publisher, 136.

[42] Levi-Strauss, C. (1955). The Structural Study of Myth. The Journal of American Folklore, 68 (270), 428-444. doi: http://doi.org/10.2307/536768

[43] Karnovsky, I., Lebed, O., (2010). Advanced Methods of Structural Analysis. New York: Springer Science, 593. doi: http://doi.org/10.1007/978-1-4419-1047-9

[44] Chandramouli, P. (2015). Structural Analysis I - Analysis of Statically Determinate Structures. Yes Dee Publishing, 1128.

[45] Kruk, R., Oort, F.; Mols, L., Buitelaar, M. (Eds.) (2015). Hajj Murals in Dakhla Oasis. Hajj. Global Interactions through Pilgrimage, Mededelingen van het Rijksmuseum voor Volkenkunde No. 43. Leiden: Sidestone Press in Cooperation with the National Museum of Ethnology, 163-183.

[46] Ministry of Antiquities (2016). Newsletter of the Egyptian Ministry of Antiquities. Cairo, 2, 1-7.

[47] Ministry of Antiquities (2017). Newsletter of the Egyptian Ministry of Antiquities. Cairo, 9, 1-8.

[48] Boozer, A. L. (2013). Archaeology on Egypt's Edge: Archaeological Research in Egypt's Dakhleh Oasis, 1819-1977. Journal of Ancient West \& East, 12, 117-156.

[49] Tawfik, M., (2016). The Concept of Sustainable Architecture and Urbanization in Dakhla and Kharga Oases in Egypt. Proceedings of the 1st International Conference on Islamic Heritage Architecture and Art. Valencia, 61-72. doi: http://doi.org/10.2495/iha160061

[50] Mohamed, M. R. (1995). Al'amay'ir Alsakaniah Albaqiah bimadinat Alqaherah fi Al'asr Al-Osmany, Derasah 'athriah watha'yiqia. Cairo: Cairo University.

[51] Yaghi, M. Gh. (2004). Manazel Alqaherah wamaqaeedha fi Al'aisrin Almamluky wal-Osmany, Derasah 'atharyh Hadariah. Zahraa ElShark for Publication. Cairo.

[52] Nabil, M. M. (2003). Derasah Tahliliah lile'amarah Alddakhiliah wal'athath lebayt El-Kredlea wa'athariha 'ala Altasmim Alddakhily wal'athath fi Almudun Aljadidah. Higher Institute of Applied Arts.

[53] John, R. G. Gayer-Anderson Pasha (2001). Legends of the House of the Cretan Woman. Cairo: American University in Cairo Press, 96.

[54] Warner, N. (2003). Guide to the Gayer-Anderson Museum. Cairo: Supreme Council of Antiquities Press, 96.

[55] Warner, N. (2005). The Monuments of Historic Cairo: A map and descriptive catalogue. Cairo: American University in Cairo Press, 392.

[56] Gayer-Anderson-Museum. Available at: https://de.wikipedia.org/wiki/Gayer-Anderson-Museum\#cite_ref-8

[57] Farghali, A. (1991). Aldalil Almujaz li'aham Alathar Al'islamiah walqibtiah fi Alqahirah. Al Dar Al Masriah Al Lubnaniah. Cairo.

[58] Al-Asad, M. (1993). The Mosque of al-Rifai in Cairo. Muqarnas, 10, 108-124. doi: http://doi.org/ $10.2307 / 1523177$

[59] Frantz, J., de Curel, R. (1869). Cirque du Caire. Revue générale de l'Architecture et des Travaux Publics, 27, 276-279.

[60] Frantz, H. (1871). Cairo's Neubauten Zeitschrift fur Praktische Baukunst, 31, 193-198, 325-330.

[61] Hillenbrand, R. (1994). Islamic Architecture: form, function, and meaning. New York: Columbia University Press, 645. 
[62] Pflugradt, E. A. (1994). La Cité d'Helwan en Égypte et son fondateur Wilhelm Reil-bey. Revue du Monde Musulman et de la Méditerranée, 73 (1), 259-279. doi: http://doi.org/10.3406/remmm. 1994.1681

[63] Reisenauer, A. G. (2008). Josef Strzygowski und die Islamische Kunst. Wien: Wien University, 108.

[64] Pflugradt, E. A. (2013). Julius Franz-Pasha's Die Baukunst des Islam: Islamic architecture of 1887 as part of the Manual of Architecture. Actes de colloques et livres en ligne de l'Institut national d'histoire de l'art. Le Caire dessiné et photographié au XIXe siècle. Paris, 1-18.

[65] Baer, G. (1968). Social Change in Egypt: 1800-1914. Political and Social Change in Modern Egypt from the Ottoman conquest to the United Arab Republic. Oxford: Oxford University Press.

[66] Vatikiotis, P. J. (1986). The History of Egypt from Muhammad Ali to Mubarak. Baltimore: Johns Hopkins University Press.

[67] Priewasser, R. (2012). Between Authoritarian Rule and Shura: Participatory Elements and Traditions in the Egyptian State since the 19th Century. Wien: Wien University.

[68] Ismail, H. (1999). Madinat Al Qahirah men wilayat Muhammad Ali “ela Isma'il"1805-1879”. Dar El Afaq El Arabeya. Cairo.

[69] Ronfort, J. (2005). André-Charles Boulle. Commandes pour le Grand Dauphin à Versailles. Dossier de l'Art, 124, 38-63.

[70] Ronfort, J. (2005). Inventaire d'un des magasins de la Direction Générale des Bâtiments du Roy à Versailles (1744-1746). Dossier de l'Art, 124, 64-65.

[71] Ireland, P. W. (1945). The Pact of the League of Arab States. The American Journal of International Law, 39 (4), 797-800.

[72] The story of Zaafran Palace. Available at: http://www.asu.edu.eg/ Last accessed: 15.02.2018

[73] Abu-Lughod, J. (1965). Tale of Two Cities: the Origins of Modern Cairo. Comparative Studies in Society and History, 7 (4), 429-457. doi: http://doi.org/10.1017/s0010417500003819

[74] Abu-Lughod, J. (1971). Cairo: 1001 Years of the City Victorious. Princeton: Princeton University Press, 284.

[75] Warburg, G. (1975). Lampson's ultimatum to Faruq, 4 February, 1942. Journal of Middle Eastern Studies, 11 (1), 24-32. doi: http://doi.org/10.1080/00263207508700285

[76] Raymond, A. (1993). Le Caire. Paris: Fayard Publisher, 428.

[77] Volait, M.; Nasr and Volait (Eds.) (2003). Making Cairo modern (1870-1950): multiple models for a "European-style". Urbanism: Imported or Exported? Cambridge: Academy Press, 17-50.

[78] Volait, M. (2005). Architectes et architectures de l'E'gypte moderne1830-1950: Gen'ese et essor d'une expertise locale. Paris: Maisonneuve et Larose Press, 477.

[79] Kramer, M. (1980). Egypt's Royal Archives, 1922-1952. American Research Center in Egypt Newsletter, 113, 19-21.

[80] Raafat, S. (2000). Island alcazar, Medina visits Maniyal Palace. Medina Magazine, 13, 84-93.

[81] Hamdy, R. S. (2010). A Study of plant distribution in nine historic gardens in Egypt. Journal of Garden History, 38 (2), 267-314.

[82] Abdel-Rahman, H. N. (2016). Egyptian Historical Parks, Authenticity vs. Change in Cairo's Cultural Landscapes. Elsevier Procedia-Social and Behavioral Sciences, 225, 391-409. doi: http://doi.org/ 10.1016/j.sbspro.2016.06.086

[83] Ferriss, J. (2017). A Tale of Two Princes. Desert Heritage Magazine. Special Edition. Milano, 88-97.

[84] UNESCO (2005). Heritage Landscape of Egypt. A New Era for Museums in Egypt. Issue No. 225-226 of Museum International. Oxford: Blackwell Publishing, 57 (1-2), 5-23.

[85] Hugh, M. (Ed.) (1980). The Royal House of Egypt, Burke's Royal Families of the World. Africa \& the Middle East. Vol. 2. London: Burke's Peerage Press, 20-37.

[86] Soliman, Ch. (2005). Zamalek: The Changing Life of Cairo Elite, 1850-1945. Cairo: American University in Cairo Press, 392.

[87] Abdallah, M. H. (2009). Qasr Al'amirah Samiha Kamil, dera'sah Me'mariah Faniyah Atharyah. Cairo: Cairo University.

[88] Hussein, A. M. (2015). Nisa' Al'usrah Al'alawiah waduarhin fi Almujtama Almisri. Cairo: Dar El-Shorouk Press.

[89] Al-aridi, G. (2014). Anwae Almaktabat Alhaditha. Amman: Academic Publishers. 
[90] El-Aref, N., (2011). Princess Samiha's former palace undergoes restoration. Available at: http:// english.ahram.org.eg/News/28212.aspx Last accessed: 15.02.2018

[91] Raafat, S. (2000). The Great Cairo Library. Cairo. Available at: http://www.egy.com/zamalek/00-01-06.php Last accessed: 15.02.2018

[92] Wilson, D. M. (2002). The British Museum: A History. London. British Museum Press, 416.

[93] Caygill, M. (2009). Treasures of the British Museum. London: British Museum Press, 240.

[94] Rose, E. (2018). Specimens, slips and systems: Daniel Solander and the classification of nature at the world's first public museum, 1753-1768. British Journal for the History of Science, 51 (2), 205-237. doi: http://doi.org/10.1017/s0007087418000249

[95] Rose, E. (2018). Natural history collections and the book: Hans Sloane's A Voyage to Jamaica (1707-1725) and his Jamaican plants. Journal of the History of Collections, 30 (1), 15-33.

[96] The British Museum. Available at: http://www.britishmuseum.org/ Last accessed: 16.01.2018

[97] MacGregor, A.; MacGregor, A. (Ed.) (1994). The life, character and career of Sir Hans Sloane. Sir Hans Sloane: Collector, Scientist, Antiquary, Founding Father of the British Museum. London: British Museum Press, 11-44.

[98] Goldgar, A. (2000). The British Museum and the Virtual Representation of Culture in the Eighteenth Century. Albion, 32 (2), 195-231. doi: http://doi.org/10.2307/4053772

[99] Delbourgo, J. (2017). Collecting the World: The Life and Curiosity of Hans Sloane. London: Allan Lane Press, 504.

[100]History of the museum. Available at: http://www.musee-orsay.fr/en/collections/history-of-the-museum/home.html Last accessed: 10.01.201

[101] Plum, G. (2007). La gare d'Orsay; The Orsay Station. Paris Nicolas Chaudun and Musee d'Orsay.

[102] Madeline, L. (2010). Musee d'Orsay 100 Impressionist Masterpieces. Paris: Scala Editions and Musée d'Orsay.

[103] Cogeval, G. (2013). Le Musée d'Orsay A 360-Degree View. Paris Flammarion and Musée d'Orsay, 360 . 